\title{
HIGH COURTS REIGN SUPREME: THE ROLE OF CASE LAW IN THE SPANISH TRANSITION TOWARDS A SECULAR (NON-DENOMINATIONAL) STATE
}

\author{
ALMUDENA RODRÍGUEZ-MOYA
}




\section{SUMMARY}

1. AIMS OF THE ARTICLE. 2. INTRODUCTION. 3. HISTORICAL BACKGROUND. 4. FREEDOM OF RELIGION IN A NON SECULAR REGIME (1975-1978). 5. THE ARRIVAL OF DEMOCRACY. THE FIRST STEPS (1978-1992). 6. THE CONSOLIDATION OF THE SYSTEM (19922009). 7. CONCLUSIONS. 


\title{
HIGH COURTS REIGN SUPREME: THE ROLE OF CASE LAW IN THE SPANISH TRANSITION TOWARDS A SECULAR (NON-DENOMINATIONAL) STATE
}

\author{
POR \\ ALMUDENA RODRÍGUEZ-MOYA* \\ Titular de Universidad \\ Derecho Eclesiástico del Estado. UNED
}

\section{AIMS OF THE ARTICLE}

The issue I am presenting today is not a new one, as the doctrine has already addressed it on multiple occasions. Yet, I understand that this matter has not yet been exhausted - far from it actually. Two fundamental reasons led me to believe this. First, Spain is no longer a religiously homogeneous society. The arrival of migrants from other countries, a trend that has increased fourfold since 1998, has led to a mushrooming of other religions. Even though the majority of the population is Catholic, there are currently about 3 million followers of other faiths in Spain, that is, $7 \%$ of the Spanish population. This is a fact that must be taken into account by public authorities. Secondly, let's remind ourselves

* The author thanks Mijiam Kunkler and Hannah Lerner for their invaluable comments and suggestions, which have greatly improved this contribution. She also thanks Fernando Val-Garijo for his help and remarks. Any shortcomings of this work are of course the sole responsibility of its author. 
that, since 2008, the Spanish Government has been considering the introduction of amendments to the 1980 Organic Law on Religious Freedom (LOLR). As a result, we can state that the debate is wide open, and that there are yet un answered questions in relation to the regulatory framework applicable to the religious phenomenon in Spain. Now, in order to gain an insight into the future of religion in our country, we have selected today a specific subject: how Spanish legal rules and case-law have evolved in Law and Religion matters ${ }^{1}$. It is a key to understanding how the present Spanish legal system protects freedom of religion. Spain was established as a social and democratic State that has taken a clear stance regarding religious issues: the principles of neutrality and separation are to operate together in order to guarantee the proper exercise of religious freedom by citizens. This, however, has not always been the case. Save for the short period of the Second Republic (1931-1936), Spain has become known for its staunch defense of the Catholic faith, and the Spanish State has traditionally been a denominational State. A long series of legal documents support this view, ranging from the Constitutions of the $19^{\text {th }}$ century to the various concordats.

The most dramatic transformation Spain has undergone since 1975 was, to be sure, the transformation of a dictatorship into a democratic State. One should not forget, however, that the country underwent a transformation no less dramatic with regard to religion-State RELATIONS. Spain tried to put her denominational past behind her, and intended to become a non-denominational State. This, needless to say, could not happen overnight. There is no question that during the period between 1975 and 2008, all branches of Spanish law have been decisively transformed by legislation, and the legal order has evolved towards a democratic system that offers protection to individual rights and freedoms. Yet one could argue that it is in the realm of Law and Religion that some of the most profound changes have taken place.

The promulgation of the 1978 Constitution, along with the establishment of democracy, was the factor that made it possible for Spain to move beyond the denominational view of the State. The Constitution proclaimed the principles of freedom, equality, neutrality among denominations and cooperation in religious matters. The Spanish Constitution explicitly refers to religion in three articles: Article 14, Article 27.3 and Article 16, which determines the constitutional stance on religious issues. But as we have announced the Religious Freedom Act might be changed, we will try to find the key of the legal reform through an analysis of case law.

${ }^{1}$ MARTÍNEZ TORRÓN, J., «Freedom of religion in the case-law of the Spanish Constitutional Court», Brighman Young University Law Review, 2, (2001). 


\section{INTRODUCTION}

The non-denominational character of a State does not depend solely on a constitutional proclamation. It is obvious that an analysis that focuses exclusively on the supreme norm does not suffice to determine whether the principles of neutrality and separation befitting a non-denominational State are respected. Such an analysis cannot tell whether religious freedom can be fully exercised. It would be a superficial approach, likely to lead us to give the wrong answer to important questions such as: Is Spain a truly non-denominational State? Does it still have features of its religious past? Issues such as religious freedom, the right to education, the teaching of religion in schools, conscientious objection or the legal status of religious denominations bear a direct relation to the individual right to freedom of conscience. Therefore, they are key issues in the analysis of what status political authorities accord the beliefs found in Spanish society.

The period under review, 1975-2008, can be separated into three phases. The first phase begins with the death of General Franco and the promulgation of the present Constitution. A second phase lasts from 1980 to 1992, when the first Cooperation Agreements between the State and non-Catholic denominations were signed. A third phase begins in 1992 when recognition of religious denominations was extended to other religions and the way was paved to grant them legal status equal to those already officially recognized.

Each one of these three phases has been shaped by a critical juncture. The first phase began with the death of General Franco in 1975 and ended in 1980, with the promulgation of the Spanish Constitution taking place in 1978. This moment is precisely the first and most consequential critical juncture, given its foundational nature and its general scope. The Constitution gave birth to a new legal and political order, irreversibly transforming the body politic. Furthermore, the new Constitution was approved by the Spanish people in a referendum, which gave the new order an extra, almost unprecedented, measure of legitimacy. Given Spain's recent authoritarian past, this democratic event was a major development that explains much of the subsequent stability of the Spanish State.

The second phase covers the period between 1980 and 1992. 1980, when the Organic Law on Religious Freedom (OLRF) was enacted, is the second critical juncture shaping religion-State relations in Spain. If 1978 was foundational, 1980 had a definitional character. The Spanish society continued to demand change, which resulted in new legislation on religious issues. The OLRF was the first piece of legislation adopted under the new political system which dealt with religious issues, now seen from a new human rights 
perspective. The ratification by Spain of the International Covenant on Civil and Political Rights in 1977 and the European Convention of Human Rights in 1979 no doubt provided a fresh context which, sooner rather than later, was to bring about deep changes in the Spanish legal conscience. Religious freedom was now seen as a fundamental right whose protection and promotion were endorsed by the Spanish State. The OLRF and the adoption of the human rights paradigm by lawmakers and the judiciary was another critical juncture that shaped the years between 1980 and 1992.

During the third phase, spanning from 1992 to the present moment, Spain has overcome its traditionally denominational past. This time the critical juncture was the signature of agreements between the State and religious entities other than the Catholic Church, a practice that started in 1992. Such agreements were signed by FEREDE (Federation of Evangelical Religious Entities of Spain), FCIE (Federation of Israelite Communities of Spain) and CIE (Islamic Commission of Spain). If the 1978 Constitution founded a new political system, and the 1980 OLRF defined a fundamental right, the 1992 agreements signified the recognition of the existing plurality in Spanish society. Thus the three critical junctures identified in Spanish recent history of religionState relations refer, first, to constitutional democracy; second, to religious freedom as a human right; and third, to the variety of religious organizations and entities whose coexistence under a fair system must be secured.

I illustrate Spain's transformation from a Catholic non-secular State to a secular, non-denominational State by looking at legislation and case-law across these three critical junctures.

After this introductory summary of the article, I believe an explanation of my selection of judicial decisions is in order. Legal rules, as applied and interpreted by the courts, effectively constitute the system a State adopts to meet the challenges issued by religious demands. Thus the study of legislation, along with the analysis of judicial decisions, is necessary if one is to know how authorities deal with freedom of conscience. The purpose in choosing particular sentences over others has been twofold: on the one hand, to highlight the legislation of each period; on the other, to check how legal rules were interpreted by the courts. It must be borne in mind that, strictly speaking, this is not a work on case-law. My method has not been to undertake a case-by-case analysis focused on the actual judicial outcome of each case. In fact, as a rule, what is important from the perspective of this work is a statement or nuance made by a court which may well be of little consequence for the case at issue, but which opens a new perspective on the reality of religious belief in this historical period. My approach, therefore, is not inductive, but rather deductive and developmental. I try to detect how the 
judiciary have construed new legal doctrines from the existing body of law and how, in so doing, the courts have effected an organic development of the law bearing on religious issues, establishing and honing a set of legal rules and principles which have gradually changed the traditional Spanish legal approach to religion.

The courts chosen for this study are two: first, the Constitutional Court, as the highest judicial body in charge of interpreting the Spanish Constitution and, secondly, the Supreme Court, whose jurisdiction covers all Spain, and is the highest judicial body in all legal branches (civil, criminal, administrative, labor and military issues), save in issues regarding constitutional rights strictly speaking. The Constitutional Court and the Supreme Court, as it is clear, have each been vested with a very different sort of jurisdiction. Moreover, as part of the Spanish legal order, the Constitution is self-executing, which means that it is directly effective. This, in turn, entails that the Supreme Court must and does apply the Constitution when deciding over the cases brought before it, although in this respect it must follow the interpretation made by the Constitutional Court. My point is that Supreme Court case-law cannot be adequately understood or assessed without reference to constitutional case-law.

Since 1975, the Spanish highest courts, that is, the Supreme Court and the Constitutional Court, have issued more than 1300 sentences on matters of religion and State $^{2}$. An examination of the general tendencies in legislation and case-law regarding freedom of religion in recent years reveals that the Highest Courts have gotten ahead of legislation in religious matters. As this paper will show, legislation and case-law do not evolve along parallel paths in matters related to freedom of religion.

\section{HISTORICAL BACKGROUND}

In Spain the Reformation, a turning point in the relation between Law and religion, was not successful. If we see Regalism as a consequence of Protestantism in Catholic countries, we can understand its connections with ecclesiastical law.

2 Options for adopting a selection criterion are many: I could have chosen the same subject in all three periods open to consideration, concentrating, for instance, on marriage, conscientious objection or religious assistance, a choice that would have narrowed my focus to a single subject and made me disregard many others. Another possibility would have been to analyze those judgments with the highest level of impact on the media. But given the different impact of the media on public opinion during the three periods under study, my conclusions would not have corresponded to reality, or been of much consequence. 
Regalism was the system of privileges granted by the Popes to Catholic monarchs in religious affairs, with the purpose of putting them on a pair with Protestant monarchs, who dealt with religious issues and could even become heads of their respective national churches. Regalism resulted in the consolidation of interference with spiritual affairs by secular powers. However, the doctrines and ideas of the French Revolution were not absorbed in Spain to the same extent as they were in the rest of Europe. The absence of anti-clerical feeling and the fact that religion was conceived as an official matter did not favour a vision of religion in terms of individual rights that are to be protected by the State.

The constitutions of the $19^{\text {th }}$ century were adopted under both liberal and absolutist governments. The traditional State religion established in Spain under the Catholic Monarchs ${ }^{3}$, and which had been in force ever since, saw its foundations quiver with the revolutionary and progressive currents which, from the rest of Europe, impregnated the spirit of the liberals or «afrancesados» («sympathisers of the French»). However, the views of this group were not always expressed in the same terms and, naturally, not all its members were in favour of absolute intolerance. The coming of the Second Republic in 1931 brought the first attempt at non-secularisation in the history of relations between Church and State. Decisions became progressively more radical until rather than being secular they became pro-secular.

The doctrine of the Second Vatican Council ${ }^{4}$ obliged the Spanish State in 1967 to modify its legislation 5 . The Catholic State under Franco's regime did not recognise religious freedom of any kind and the Penal Code, with its religious offences, was living proof of this ${ }^{6}$. However, recognition of religious

3 Vid. DE LA HERA, A., «Los orígenes de la Confesionalidad y de la libertad religiosa en el Derecho constitucional español» in Anuario de derecho eclesiástico del Estado, n. ${ }^{\circ}$ 24, 2008.

${ }^{4}$ CORRAL SALVADOR, C., "Repercusión de la Declaración conciliar "Dignitatis Humanae" sobre la confesionalidad católica del Estado español», in Revista Española de Derecho Canónico, XXI, 1966, at 269 et seq.

5 SUÁREZ PERTIERRA, however, is right to point out that a statutory project had already been drafted which would regulate the situation of non-Catholics in Spain. SUÁREZ PERTIERRA, G., Libertad religiosa y confesionalidad en el ordenamiento jurídico español, Vitoria, 1978. at 36 also collate: BERNÁRDEZ CANTÓN, A., Elementos de Derecho eclesiástico español, Pamplona, 1974, pp. 401 y ss., CORRAL SALVADOR, C., «La ley española de libertad religiosa ante el Derecho comparado en Europa occidental», en Revista Española de Derecho Canónico, XXI, 1967, pp. 623 y ss., MARTÍN MARTÍNEZ, I., «La libertad religiosa en la Ley Orgánica del Estado" en Revista de estudios politicos, 182, 1972, pp. 181 y ss., PÉREZ LLANTADA, J., La libertad relgiosa en España y el Vaticano II, Madrid, 1974.

${ }^{6}$ Law and religion crimes: CUELLO CALÓN, E., «La protección penal de la religión», in «REDC», 9 (1954), at 923-929., RODRÍGUEZ DEVESA, J. M., «Delitos contra los sentimien- 
freedom by the Holy See meant that the Spanish government had to modify its legislation on religious matters, which led to the 1967 Religious Freedom Act. As Fornés noted, «One does not have to go into too much depth to understand that this law obeys to the need, (...), to model State legislation on the doctrine of the Church» ${ }^{7}$. From a historical perspective, the Second Vatican Council can be considered as yet another critical juncture, which saw the Catholic Church embrace the doctrine of freedom of religion. This fact brought about an irreversible change in relations between the Catholic Church and the State. Curiously enough, religious freedom did not come in the same guise as in the secular, non-denominational State, that is, freedom of religion was not founded on State neutrality and separation between church and State. On the contrary, it was for the denominational, non-secular State to protect the «new right» to freedom of religion.

\section{FREEDOM OF RELIGION IN A NON SECULAR REGIME (1975-1978)}

Legislation from the Franco era was rich in references to the non-secularity of the State. Some of the most relevant examples can be found in Article 5 of the 1953 Concordat, in the second principle of the National Movement, in Article 6 of the Spanish Code of Laws and in the First Law of Succession. All these provisions defended official protection of religion and the Catholic religious State, and some alluded to minimum tolerance. However, as a result of the Second Vatican Council (1962-1965), two Church documents were to unexpectedly change the direction of relations with the Holy See: the Pastoral Constitution Gaudium et Spes and the Dignitatis Humanae Declaration.

The Second Vatican Council embraced the doctrine of religious freedom, which meant that for the first time the Catholic Church recognised the existence

tos religiosos», in "Estudios de Deusto», XIII(1965), at 635-651., FERNÁNDEZ CORONADO, A., La tutela penal de la libertad religiosa, en «ADEE», II(1986), at 17-55., PÉREZ-MADRID, F., La tutela penal del factor religioso en el Derecho español, Eunsa, Pamplona, 1995., ROSSELL, J., Religión y jurisprudencia penal. Un estudio de la jurisprudencia de la Sala $2^{a}$ del TS en el periodo 1930-1995, Ed. Complutense, S.A, Madrid, 1996., FERNÁNDEZ-CORONADO, A., «El contenido de la libertad de conciencia en el Código Penal de 1995", in Revista del Poder Judicial, 52 (1998), at 135-176, FERREIRO GALGUERA, J., Protección jurídico penal de la religión, Servicio de Publicaciones de la Universidad de La Coruña, La Coruña, 1998.

7 FORNÉS, J., Elementos de Derecho eclesiástico español, Derecho Canónico, AAVV, Pamplona, 1977, at 790. 
of other religions as possible roads to salvation. This position was to create serious contradictions within Spanish legislation. The defence of the Catholic religion as the only true religion proclaimed by Spanish law was now incompatible with the freedom of religion proclaimed by the Vatican itself. The Second Principle of the National Movement stirred the authorities to adapt legislation to the magisterium of the Church. Thus, in 1967, the 2nd paragraph of Article 6 of the Spanish Code of Fundamental Laws was modified and made to read: "The State will assume the defence of freedom of religion». Before this modification, Article 6 of the Charter of Spanish Nationals (Fuero de los Españoles), echoing the $19^{\text {th }}$ century tradition, did not allow any external manifestation of religious faith other than Catholic ${ }^{8}$. That same year the Freedom of Religion Act was passed. This piece of legislation did not completely satisfy non-Catholics, because it contemplated freedom of religion as a mere recognition of tolerance. Furthermore, Act 44/1967 was to be exclusively applied to non-Catholic cults, reserving a different regime for the Catholic Church - a situation which still exists today. The limits established by the text created a false system of religious freedom ${ }^{9}$.

Still in 1975, certain regalist privileges could be found in Spanish law: civil authorities nominated candidate bishops, official church mail needed no postage, crimes and misdemeanours allegedly committed by priests could be tried by church courts. On $28^{\text {th }}$ July 1976, Spain and the Holy See signed an agreement that brought an end to these privileges, which were enshrined in the so called code of law and presentation. This agreement was proof of Spain's desire for change. Like the Second Vatican Council and the 1967 Act, this agreement prepared the ground for the first critical juncture in State-religion relations. The privilege of presentation obviously meant that the State could be safe in the knowledge that the dioceses were not guided by bishops who opposed the established order. In this context, the fact that the State was prepared to forgo this privilege was a sign of good faith. The 1976 Agreement between Spain and the Holy See stated the need for a reform of the Concordat of 1953, and the Agreement of 1941, by which the Government had committed itself not to legislate on «mixed affairs», was annulled. In Spanish jurisprudence, the so

${ }^{8}$ Charter of Spanish Nationals, Article 6: The profession and practice of the Catholic religion, which is the religion of the Spanish State, will be officially protected. No one shall be disturbed on account of his religious beliefs or the private exercise of worship'. No ceremonies or external manifestations of religious faith other than Catholic shall be permitted.

9 The system was false because for a true system of religious freedom to exist, two key elements must concur: State neutrality and separation between church and State. None of them existed, given the official profession of faith made by the State. 
called mixed affairs were those jointly regulated by civil and church authorities. A classical example was marriage, whose regulation was also entrusted to the Catholic Church, save for the historical periods of the First Republic (18731874), and the Second Republic (1031-1936). But since 1976 the State took over the regulation of mixed affairs, thus ending their mixed character. This too marked the beginning of the change that was about to come.

Regulations at this time were non-secular, yet tolerant. Rather than a legal statute guaranteeing freedom of religion, for instance, there was in fact protection of the Catholic faith as the State religion. This can best be seen in the realm of Criminal Law ${ }^{10}$. In 1975, protection of religious sentiment travelled in a single direction: towards Catholic sentiment. Spain was a denominational country where all laws and regulations reflected the faith professed by the State ${ }^{11}$. The special protection which religious sentiment received was clearly established by case-law, as will be seen by the sentences used as examples.

The offence which best reflects this theory is that of blasphemy. According to the sentence of 18th March, 1975, blasphemy required two elements: conduct (objective) and intention (subjective). The appellant referred to the non-existence of serious scandal. That blasphemous conduct had taken place was not denied in this case; what was put in question was that such conduct amounted to the offence of blasphemy. The blasphemous words were uttered under the influence of alcohol, which in the opinion of the Court removed voluntary intent in a predominantly intentional offence ${ }^{12}$. The Court esteemed that the commission of the offence «laid down in article 239 of the Penal Code regarding verbal blasphemy, apart from being public, requires the existence of serious scandal. The lack of this essential

10 In Spain, the protection granted by law to religious affairs has varied from 1975 to our days. In Spanish Criminal Law: «1. Jibe: 1 July 1975 (3050)2, 13 October 1980 (3696), 12 May 1973 (2022), 26 November 1990 (9163), 13 October 1980 (3696), 19 February1982 (673), 25 January 1983 (48), 23 March 1993 (3152), 8 April 1981 (1610), 14 February 1984 (766), 20 May 1988 (3698), 26 November 1990 (9163), 1 July 1975 (3050); 2. Desecration: 15 July 1982 (4670),10 December 1982 (7399), 25 March 1993 (3152): 3. Blasphemy: 18 March 1975 (1183), 14 May 1977 (2285), 31 March 1979 (1448); 4. To impede the exercise of the right to religious freedom: 23 March 1993 (2500)».

${ }^{11}$ Curiously enough, the protection of religious sentiment today is reminiscent of that enjoyed by the Catholic Church some years ago. I shall try to explain this by saying that with the arrival of democracy, the protection granted is not to any concrete religious belief but to the religious sentiment of citizens, although the law apparently provides special protection to religious sentiment, setting it apart thus from any other.

12 This affirmation reminds us of the special «animus» requirement, both in desecration and jibe, although the Court does not consider it a requirement in the offence of blasphemy, despite direct references to it. 
punishable element transforms the conduct into a simple offence of non-scandalous blasphemy as described in article 567.1 of the Penal Code».

In its sentence of 14 May 1977, the Supreme Court ruled that the offence of blasphemy had a doubly illegal nature, as it considered blasphemy a religious offence insofar as it constituted an attack on God and at the same time a violation of the rules of public co-existence. It also added a third punishable element which in a secular system would replace the first element mentioned, that is, an infringement of the religious sentiments of the community. The Court pointed out that Canon Law distinguishes between heresy and blasphemy, at which point the Court corrected itself, stating that the offence of blasphemy contemplated in the Penal Code does not punish the slanderous reference to God but the offence against elementary public co-existence. Heresy is contemplated by very few legal systems due to the prevailing freedom of religion, the sole survivor being imprecative blasphemy ${ }^{13}$. The Court pointed out that, in determining whether blasphemy had been committed, both deeds and words were to be taken into account, with the exception of oral or written blasphemy by mockery and ridicule. Scholarly opinion, for its part, understands that only immediate blasphemies against God are punishable, where God means any of the three persons of the Holy Trinity, or blasphemy against the Sacred Forms, that is, the bodily nature of the Body and Blood of Christ. Moreover, it is evidently not going too far to say that blasphemies are "convitium contra Deum vel Santos». Once again reference is made to the essential requirements for the offence of blasphemy to exist: serious scandal of a public nature ${ }^{14}$, requirements which can be considered as just one because a major scandal can only take place in public. The Court, analysing the above jurisprudence, pointed out that acts would be considered blasphemous if carried out in public places, buses, bars, streets, that is, places where other people gather ... It may seem that this criteria changed with time. For instance, in the case of mockery of religious sentiment in a public place such as a theatre, mockery would lose its blasphemous nature because attendance to the theatre is indeed voluntary. What has actually changed is the concept of serious scandal, as those who go into a certain place out of their own free will, in full knowledge of the kind of place they are attending, cannot be scandalized unless they deliberately choose to be.

13 This would mean that actions considered to be blasphemous should be included in the offence of mockery; a distinction made by the law between both types would lead to the belief that blasphemy was a minor mockery.

14 STS 31 March 1979 (1448) The Supreme Court thinks there is no serious scandal, because bars are places where people swear. 
Offences such as mockery, blasphemy and profanation are aimed at one thing, the protection of the official religion. The enactment of the Freedom of Religion Act of 1969 extended this protection to recognised religions; this protection was to take a long time to come into effect in case-law. Along with the Catholic religion, ministers or members of these religious orders or entities also enjoyed special protection, including parish priests who were authorities to relevant penal effects. This protection has now disappeared both from legislation and from case-law ${ }^{15}$.

The change from a denominational to a secular State, it will be seen, accounts for changes in case-law with regard to offences protecting morals. At first an indirect penalty for attacking the religious principles of society is likely to exist. Religious principles can be later replaced by ethical sentiment, which bear no relation to religion.

Another realm in which the protection of the Catholic faith manifested itself as the dominant element in religion-State relations in this period was the choice of Sunday as the day of rest. When it was a non-secular, denominational State, Spain had to respect divine ruling and legislate accordingly. In order to renew the Catholic tradition of social justice and to fulfil religious requirements, legislators understood that appropriate regulations should be adopted that would ensure respect for the holidays (holy days) of the Catholic Church ${ }^{16}$. The Act dated $13^{\text {th }}$ July, 1940 establishing Sunday as a day of rest reflected the will of the Spanish State regarding labour matters.

The Supreme Court in its sentence of $29^{\text {th }}$ September, 1975 (3978), which attempted to elucidate whether the petitioner did or did not have the right to work on Sunday, defined the reasons for maintaining Sunday as a day of rest. It justified the choice of that day of rest by a number of reasons, considering that besides being a means to sanctify holidays, it was meant to provide both self-employed individuals and those on pay-roll, to quote the Court, «a period of rest to attend to one's personal and family needs».

This was not, however, an absolute rule allowing no exception. To be exempted from compliance, a certain set of circumstances was required, in addition to an authorisation from the Department of Labour. The petitioner, interpreting religious connotations as the sole reason for respecting Sunday as a day of rest, considered ecclesiastical authorisation both valid and sufficient to remove the prohibition of working on Sunday. However, the Court, on this count, ruled that authorisation by the ecclesiastical authority was not sufficient to permit

1519 May 1975 (2153), 18 March 1982 (1724), 25 November 1976 (4936).

16 Vid Law on Sunday Rest, 13 July 1940. 
working on Sunday, and that authorisation by the relevant public Administration Department was also necessary. A few lines further down the Court reaffirmed its criteria by stating that «the work for which the removal of the prohibition is requested in these particular circumstances requires the concession of authorisation from the Labour Administration Department; this authorisation, as previously stated, may not be replaced by that of the ecclesiastical authority».

It is clear, then, that the only valid authorisation is that of the relevant labour affairs organ of the State, and that ecclesiastical authorisation is of no use whatsoever. It may thus be inferred that the reasoning behind maintaining Sunday as a day of rest is not merely of religious nature, or even that ecclesiastical authorities have no power of exemption at all. It could be said that the sentence is a "secular sentence», as in a non-secular State, like Spain at this time; the ecclesiastical authorities were not taken into account when determining whether working on Sundays was lawful or not.

With the changes that took place in Spain once the Constitution was adopted, and Spain was established as a secular State, new questions arose ${ }^{17}$. The Workers' Statute, in its Article 37, states that workers must have one and a half days of consecutive rest per week. The legal text itself states that this weekly rest is to include all Sunday and either Saturday afternoon or Monday morning. A different work schedule may be determined by law, collective agreement or authorised licence for certain activities.

\section{THE ARRIVAL OF DEMOCRACY. THE FIRST STEPS (1978-1992)}

It was the founding of democracy combined with the enactment of the 1978 Constitution which, by overcoming the denominational nature of the

${ }^{17}$ After the Constitution came into effect, the rationale for Sunday rest changed. In its sentence of 20th April, 1988 (2999) the Supreme Court made it clear that the choice of Sunday as a day of rest by the relevant labour regulations was only based on secular and working tradition. By stating this, the Court removed any kind of religious connotation from Sunday rest, so it is clear that the Court's conception has changed, as in the previous sentences it recognised the religious reasons behind establishing Sunday as a day of rest. The change was not, however, very abrupt, as the Court had already begun to reflect on the importance for workers to have the right to time off each week, Sunday or otherwise. That is to say, during the first phase of change the notion of having a resting day during the working week had two origins; religious factors and mere labour considerations, and afterwards this notion was based solely on workers' rights, while tradition, or perhaps inertia, maintained Sunday as the traditional day off. 
State ${ }^{18}$, and by introducing the principles of freedom, equality, neutrality in religious affairs and co-operation regarding religion, allowed the emergence of a complete new system of Law and Religion ${ }^{19}$. As SUÁREZ PERTIERRA ${ }^{20}$ points out, the Spanish Constitution of 1978 laid down the framework for settling the endemic religious question in Spain. This same author, one of the Spanish leading scholars in the field, has affirmed that basically three factors have led to the actual constitutional transformation. In the first place, the Constitution, as already mentioned, introduced a model based on a set of higher values or principles which formed what have been labelled as "fundamental rights». The right to freedom of ideology, religion or worship, freedom of conscience, in fact, «includes freedom of opinions, ideas and beliefs, the right to forming one's own conscience, freedom of expression of one's own opinions and freedom not to be prevented from acting in accordance to these and not to be compelled to act against them... this is - as we will have occasion to explain - one same, indivisible freedom, whose essentially unitary nature is manifest in different ways».

The second element noted by SUÁREZ PERTIERRA is the secular nature of the State. Secularity has three consequences: State neutrality- which does not necessarily mean proactive secularity, separation of the Church and the State and

18 Collate: LLAMAZARES FERNÁNDEZ, D., SUÁREZ-PERTIERRA, G., El fenómeno religioso en la Constitución española, pp. 29-33.

19 Collate OLMOS ORTEGA, M. E., «Estado actual de la ciencia del Derecho eclesiástico español», in ADEE (1987), at 210-211. IBÁN advances a different view: "It is undisputable that the Constitution has established some "game rules" that so far have been proven effective, but the trend towards a "natural law" understanding thereof is not without peril. Other game rules are possible; the Constitution cannot be considered as an unchangeable absolute whole, for it has established rules providing for its very amendment" or "To sum up, without intending to underestimate the importance the Constitution may have in our system of sources of law, I should like to remind that it is a legal norm, and that those who engage in scholarly interpretation of the legal order must take it into account, but also the rest of the legal order and, if I may say it, that other part of the legal order must be presumed to be in accordance with the Constitution, unless the competent organ declares otherwise». IBÁN, I. C., "Sistema de fuentes del Derecho eclesiástico», in, IBÁN, I. C., PRIETO SANCHÍS, L., MOTILLA DE LA CALLE, A., Curso de Derecho eclesiástico, Madrid, 1991, at. 38. Along the same lines, GONZÁLEZ DEL VALLE: "Nowadays the Ecclesiastical Law scholar is usually a hyper-constitutionalist», GONZÁLEZ DEL VALLE, J. M., Derecho eclesiástico español, Madrid 1989, at. 106, also collate: REINA, V., REINA, A., Lecciones de Derecho eclesiástico, Barcelona, 1986, p. 247, LOMBARDÍA, P.,» La relación entre el Derecho canónico y el Derecho eclesiástico", in Ius Canonicum, 1982, p. 16, MARTÍNEZ TORRÓN, J., Religión, Derecho y sociedad, Granada, 2000.

${ }^{20}$ Keynote Speech at the V Symposium of the Spanish Society of Sciences of Religion, «Religion, Religions, Identity, Identities, Minorities», Valencia 1-3 February 2002. 
autonomy of both. It should neither be confused with the idea of positive secularity, as the author points out: «The neutrality of the State does not entail an axiological detachment, only that social ethics and religious ethics are not the same thing. Secularity is not indifference; it is the demand for freedom, it implies the neutrality of public authorities and the promotion of freedom in material terms, and not just in the formal terms laid down in the Constitution itself».

As a third element acting as an agent of transformation, this author points to the principle of tolerance in the constitutional process. The system created by the Constitution is complex, so as to favour consensus. This reality produced the ambiguities of art. 16.3, a provision, however, not intended to be interpreted in a totally discretionary manner. The framework regulating the position of the State as opposed to the religious factor aims to alleviate the tensions produced by a certain amount of belligerence.

GONZÁLEZ DEL VALLE21, referring to the Constitution, states that "there are three precepts in which express reference to religion is made: Article 14, Article 27.3 and Article 16 - the most important for ecclesiastical Law which were drawn up to point out the position of the Spanish Constitution regarding religious affairs.»

Since Article 16 of the Constitution provides the major pillar of religious freedom after 1978, a study of the case-law derived from it reveals important.

Article 16.1 guarantees freedom of ideology, religion and worship of private individuals and communities, which refers to two concepts: the individual and also the group or community.

Article 16 is located in the first chapter of the Constitution, which indicates that it refers to a fundamental right. The protection of freedom of religion covers two aspects. On the one hand, that of providing the legislation developing and providing for this right, and on the other, what I shall call judicial protection thereof. It could be said that the right to freedom of conscience enjoys privileged constitutional protection ${ }^{22}$. The protection of fundamental rights is different from, and takes preference over, other kind of rights, such as constitutional rights or mere civil rights. Soon the right became developed in 5/1980 $\mathrm{Act}^{23}$.

${ }^{21}$ GONZÁLEZ DEL VALLE, J. M., Derecho Eclesiástico, op. cit., at. 105.

22 SOUTO PAZ, J. A., Derecho Eclesiástico... op. cit., at., 287-291.

23 CIÁURRIZ, M. J., La libertad religiosa en el Derecho español. La Ley Orgánica de Libertad Religiosa, Madrid, 1984., CONTRERAS MAZARÍO, J. M., "La libertad de conciencia y la función promocional del Estado en la ley orgánica de libertad religiosa", in Laicidad y Libertades. Escritos Jurídicos, 0(2000), pp. 135-173. 
In its sentence of $23^{\text {rd }}$ March 1993 (2500), the Supreme Court tried to determine "whether belonging to a religious sect such as the one in question constitutes a right accepted by the Law, or if, on the contrary, given the teachings and mission of this sect, it is of clandestine nature». This sentence allows us to see what this High Court considers to be the individual aspect of freedom of religion. The Supreme Court even evaluates beliefs, understanding that one thing is to believe in certain dogmas, and quite another to express these beliefs outwardly, which, in our opinion, is not a proper function for a secular State which aims to be neutral. When limiting the conduct of private individuals, the Court points out that regarding freedom of «internal» belief no kind of coercion may be exercised; however, what may be limited by law, whether administrative or criminal, is the outward expression of such beliefs. If derived from ideas which, if carried out, are destructive for other persons, or if the means used to maintain beliefs, or if the means used for recruiting followers are deemed to be dangerous, religious conduct may be forbidden.

The Supreme Court understood that the petitioners were not exercising civic duties as members of the «sect called C.E.I.S.» The «sect» in question was not of religious nature and aimed, through clandestine activities, to uproot its followers, inciting them to prostitution for financial gain by the leaders. It is therefore obvious that the use of illicit and illegal means such as proselytism cannot be considered as precisely a form of public spirit. It is interesting to note on reading the sentence that proselytism was considered illegal at that time, when today in Spain it is deemed to be part of the fundamental right of religious freedom. This is also reflected in the sentence issued by the European Court of Human Rights in the Kokkinakis case ${ }^{24}$. Nevertheless freedom of belief reaches its most evident limit when negatively expressed: in the right of those targeted by proselytizing activities not to believe, or not to approve of, or not to bear acts of proselytism ${ }^{25}$.

In the case under scrutiny, the Supreme Court referred to the collective aspect of religious freedom when it linked the beliefs of individuals to their membership of a certain religious community.

The Spanish legal order created a system whereby not all religious groups were allowed to exercise the right to freedom of conscience in the same way ${ }^{26}$,

24 "Proselytism is linked to religious freedom; believers can communicate their faith and convictions both in the religious sphere and in the philosophical sphere». SSHRT 25 $5^{\text {th }}$ May, 1993, Kokkinakis Case.

25 STC 141/2000.

${ }^{26}$ Collate: PALOMINO LOZANO, R. «Iglesias, Confesiones y Comunidades Religiosas: el concepto legal de confesión religiosa en la LOLR y la doctrina", in Revista General de Derecho 
thus forming a sort of Kelsenian pyramid. At the top would stand the Catholic Church, even though the signature of the four agreements, still in force today ${ }^{27}$, between the Spanish State and the Holy See was to take another four years. This was mainly due to the transitional situation of Spain and to the drafting of the Spanish Constitution, policy considerations derived from these facts were considered more than sufficient for postponing the signature of the agreements. However, if we take into account that the Constitution was passed by Parliament in plenary sessions of both Congress and the Senate on $31^{\text {st }}$ October, $1978^{28}$, and that the agreements were dated on $3^{\text {rd }}$ January, with ratification on $4^{\text {th }}$ December, it cannot be said that they were drawn up after the Constitution and even less that they led to the development of the principle of cooperation which the Constitution establishes in article $16^{29}$. On the second rung of the pyramid, then, the Approved Religions (by the agreements) would be found, whilst on the third rung the registered religions would be located, and lastly, with minimum protection, other religious groups would find their place at the bottom.

The first step towards recognition of Religions would be their registration in the Religious Entities Register (RER). The requirements established by our legislation have been discussed on various occasions in Spanish case-law ${ }^{30}$. The sentence dated on 2nd November, 1987 (8764) discusses each of these requirements and establishes the appropriate standard for their interpretation.

In 1986 the "Christian Church of the Carmelites of the Holy Face of El Palmar» was denied the right to register in the RER, which resulted in the legal proceedings culminating in the sentence issued on $2^{\text {nd }}$ November, 1987 (8764). This sentence contained an analysis of the requirements for registration

Canónico y Derecho Eclesiástico del Estado, n. ${ }^{\circ}$ 19, 2009, MURILLO MUÑOZ, M., "La eficacia constitutiva de la inscricpción en el Registro de entidades religiosas» in Laicidad y libertades: escritos jurídicos, ISSN 1696-6937, n. ${ }^{\circ}$ 0, 2000, pp. 201-228 and PELAYO OLMEDO, J.D., Las Comunidades ideológicas y religiosas. La personalidad jurídica y la actividad registral, Madrid, 2007.

27 Also collate: Convention of 5 April 1962, on Civil Recognition of Non Ecclesiastical Studies followed at Catholic Church Universities (BOE n. 173, 20 July 1962). Agreement between the Holy See and Spain, signed in the Vatican City on 28 July 1976. (B.O.E. 24 September). Agreement between the Kingdom of Spain and the Holy See on Matters of Common Interest in the Holy Land, 21 December 1994 (BOE n. 179/1995, 28 July 1995).

${ }^{28}$ Ratified by referendum on 6 December, and published in the BOE. on 29 December 1978.

29 Vid, IBÁN I. C., Curso de Derecho..., op. cit., at. 149.

3014 June 1996 (5082), 18 June 1992 (6004) 21 June 1996 (4967), 5 November 1979 (4014), 28 November 1986 (6622) 1 March 1994 (1659), 6 October 1997 (6968), 2 November 1987 (8764), 11 July 1989 (5349), 25 June 1990 (5700), 13 January 1999 (269) . 
and the legal nature of the aforesaid registration. In this respect the Court considered that the applicable legal rules «contemplate religious communities, including its federations, as a sociological reality prior to any recognition of its legal status by the State ... the function of the State in this regard is one of mere formal recognition by means of registration which, insofar as it confers such communities their legal character, is only legally effective from this date, but this function may not go further than registration of formal aspects such as its individual denomination, address, aims and functioning. Registration may only be denied when its individual character is not properly determined.

With regard to its denomination, the Supreme Court considers the features of the new Church sufficient to differentiate it from other Christian churches. In the first place, its name alludes to its location: El Palmar de Troya, in the Province of Seville. The Supreme Court, curiously enough, adds that a decisive factor in the individual nature of the above mentioned Church is the social impact it has had, so that it would be difficult to confuse with any other church «at least in Spain, where the legal status has been requested». The study of the aims of this religion will obviously not deny its individual character. In the first place, because such aims will always be religious, and secondly, because in the case of all Christian churches the aims will coincide with some basic ideas ${ }^{31}$. The Court maintained the same position regarding the way in which the religion in question operated, admitting that the existence of certain parallels is nonimportant. The essential nature of the fourth requirement for registration as a religious entity is the registration of the above mentioned details, in order for them to be public and, if it were necessary, to facilitate that personal contacts be made in state dealings with the religion or religious entity in question.

From the analysis made by the Supreme Court of the requirements for registration, it may be inferred that both the denomination and the address are the two pieces of information giving it its individual character, data which cannot coincide with those of any other religion; however, regarding the aims, the only purpose is to inform followers of this religion, irrespective of the coincidences that such aims may have with those of other churches or religions. The religious aim is the defining feature of the religious entity; under no

31 «What is intended by the requirement of stating the aims of the institutional organism created is to check whether such aims are of a religious nature ... to expect, as sustained by the sentence, further details, to make distinctions between different Christian ecclesiastical organisations, would be to demand details not included in the legal text and its implementing Regulations, which recognise the plurality of differing beliefs, all of which lead to a single goal: the need of man for religion, as a spiritual being, with God». 
circumstances would it suffice to have a mere interest, albeit religious. This was how the Supreme Court ruled in its sentence of $1^{\text {st }}$ March, 1994, taking case $142 / 1981$ to its final conclusions when, in order to permit registration in the Religious Entities Register, it deemed they should have «religious aims». In view of the meaning of the word «religion» in Spanish, we may say that an entity has «religious aims» when its fundamental purpose is to group together persons who share the same beliefs on divinity, considering this doctrine common for them, pray and preach such beliefs, or, in the case of foundations, allot a set of assets to the aforementioned aims». Therefore it could be said that, in this period, the courts understood that the analysis and requirement of religious purposes in the communities mentioned in Article 16.1 were essential.

\section{THE CONSOLIDATION OF THE SYSTEM (1992-2009)}

The best choice for the last period under consideration is to focus on the years between 1992 and the present day. In 1992, protection was extended to other religions and the way was paved to give them a legal status equal to that of the Catholic Church. Equal status does not mean, however, egalitarian status ${ }^{32}$ . Agreements have been concluded between the State and the Federation of Evangelical Churches of Spain (FEREDE), the Federation of Israelite Communities in Spain (FCI) and the Islamic Commission in Spain (CIE) (Acts 24, 25 and 26 of $11^{\text {th }}$ November, 1992). Recognition was provided based on criteria such as a sufficient presence in Spanish society, minimum numbers granting access to religious instruction, and co-operation with the State according to available means.

The conclusion of these agreements is no doubt a critical juncture in religionState relations in Spain. The 1992 agreements reaffirm the recognition of religious freedom of the entities concerned, granting them a status more similar to that of the Catholic Church. Thus, members of the various federations and

32 The principle of religious equality has two different aspects. On the one hand, equality can be understood as equal treatment by the authorities to people and religions when applying the Law, and on the other hand, equality within the Law itself. In the first case it is assumed that legal regulation should produce an identical result all things being equal. Equality within the Law requires a more detailed analysis. It is easy to understand that uniformity is not possible in dealing with all people and situations. Therefore, legislators will see their efforts thwarted if they try to treat different situations and people in the same way, or the same people or situations in a different way. Equality should be understood within the context of a Social and Democratic Rule of Law in which positive discrimination is an indispensable legal principle. 
commissions that signed the agreements were granted the right to religious service and assistance, the right to religious instruction in public schools, the right to celebrate public holidays and religious rites. Although the possibility of tax exemptions is mentioned in the agreements, no system of fund raising or collection by the State for the churches is designed in them ${ }^{33}$. The reason was, in all likelihood, that the State had already made a choice favouring the selffinancing of churches and religious entities, a choice already manifest in the 1979 Agreement on Economic Affairs signed between Spain and the Holy See.

The federations that signed these agreements (of recognition) with the State of Spain followed a number of procedures before registration. At first, the rigid nature of the Register was maintained, and the Supreme Court followed suit. In its sentence of $14^{\text {th }}$ June, 1996 (5082), the Church of Unification, appealed a sentence issued by the National High Court (Audiencia Nacional) denying its right to register in the Religious Entities Register. The Court ruled that the Administration should take the utmost care when analysing compliance with the requirements, and therefore there should be in-depth control. Registration should be preceded by an assessment which would not only examine the formal requirements, but also the real contents of faith, materials or background of the entity requesting registration, and, in particular, those which guaranteed that the aims expressed in the request for registration were respectful of «the limits established by article 3 of Act 7/1980, at the service of the rights derived from religious freedom», limits which were defined in this precept as the «safeguard of public health and morals». The Court concluded by reasoning that in order to be registered in the RER this sort of in-depth analysis was necessary and registration should be denied in the event of doubts as to whether the entity was really religiously orientated or whether the aims were really religious, or whether the activities to be carried out by the applicant could constitute a risk for public order as defined by the Freedom of Religion Act. This doctrine, however, was modified by the supreme interpreter of the Constitution in the Spanish system, which is no other than the Constitutional Court.

The Constitutional Court, in its sentence 46/2001, referred to the interpretation of article 18.1 of the Universal Declaration of Human Rights made by the United Nations Human Rights Commission in its General Comment of 20 July 1993, according to which this precept "protects theistic,

${ }^{33}$ No religious taxes exist in Spain. There is, however, a system whereby the State manages a part of the revenue of the Catholic Church, giving citizens the opportunity of choosing to earmark $0.7 \%$ of their income tax payments to the Catholic Church. This system applies exclusively with regard to the Catholic Church. 
non-theistic and atheist beliefs, as well as the right not to profess any religion or belief; the terms belief or religion are to be understood in the broadest sense», adding that «article 18 is not limited in its application to traditional religions or to religions and beliefs with institutional features or practices analogous to those of traditional religions». The Court considered the action of the Register as restrictive. It understood that the organisation of a Register to serve this purpose did not authorise the State to carry out any activity controlling the legitimacy of the religious beliefs of the religious entities or communities, or of the different means of expressing such beliefs. The Register should merely ascertain that the entity requesting registration was not one of those excluded by art. 3.2 of the Freedom of Religion Act and that its activities or conduct did not impinge on the right of others to exercise their liberties and fundamental rights, and that they did not pose a threat to public safety, health or morality, as these were basic features of the public order protected by the law in a democratic society, as mentioned in art 16.1 CE.

The Constitutional Court, therefore, states that, «by means of this check the administrative authority responsible for this organ is not to act according to its own discretion, nor is it granted a certain measure of personal choice as to whether or not the registration should be granted; on the contrary, its function in this regard can only be described as regulated, that is, as predetermined by law. This is confirmed by article 4.2 of the Regulations concerning the organisation and functioning of the Register (Royal Decree 142/1981, of $9^{\text {th }}$ January), which states that «registration may only be denied when the required details referred to in article 3, such as denomination, address, organisational system and representative organs, or religious aims are not duly provided».

In this same sentence the Constitutional Court states that the content of freedom of religion «has no limits when protecting against external interference within the sphere of individual or collective liberty which allows people to act in accordance with the creed they profess (SSCT 19/1985), if 13th February, 120/1990, of 27th June and 63/1994, of 28th February, amongst others), as there is clearly an external dimension to freedom of religion entailing the exercise of this freedom in public, immune from all coercion by public authorities, which materializes in activities which constitute demonstrations or expressions of a religious nature, made by religious communities, such as those listed in article 2 of the LOLR, and regarding which public authorities are to have a positive attitude, focused on what may be called care and attention, both of which are mentioned in section 3 of the above-mentioned article 2 of the LOLR. According to this provision, "for the real and effective exercise of these rights [those listed in the two previous sections of the Act], public 
authorities are to adopt the necessary measures to provide religious services in public establishments under its control, such as military premises, hospitals, welfare institutions, penitentiary centres and others, in addition to religious instruction in public schools and centres of learning». And as a special expression of this positive attitude regarding the collective exercise of freedom of religion, its collective manifestations or conduct, article 16.3 of the Constitution, after making a declaration of neutrality (SSCT 340/1993, of $16^{\text {th }}$ November, and $177 / 1996$, of $11^{\text {th }}$ November), considers the religious factor to be present in Spanish society and orders that public authorities maintain «the appropriate relations of cooperation with the Catholic Church and other religions», thus introducing an idea of positive secularity which «prevents any kind of confusion between religious and State aims» (SCT 177/1996).

To conclude, I believe a reference to the limits of the right to freedom of religion in our legal system is essential. The limits of the right to freedom of religion are the same as the limits to any other fundamental right: the need to preserve other fundamental rights, respect for constitutional values and principles and, of course, for Public Order, a concept which is difficult to define as it may vary in the course of time, because it depends directly on the values that prevail in society at the time of its interpretation. The real problem of a clash with rights lies in establishing priorities in the event of a conflict between two fundamental rights or constitutional values.

In order to establish such priorities it is essential to resort to case-law and I believe a reference to the sentence of $27^{\text {th }}$ June, 1997 (4987) is in order. This sentence is the outcome of a case in which the parents of a minor where accused of homicide because they invoked conscientious objection to refuse the medical treatment proposed to cure the child. As it has already been observed, freedom of conscience is not protected absolutely. In this particular case, conscientious objection to a particular medical treatment is an example of the conflict between freedom of religion and the right to life. The Court determines that the proper way to decide the case is to establish that one fundamental right prevails over the other.

The Supreme Court stresses the difference that exists when conscientious objection is invoked by a minor or a legal adult. In the case of adults, their decision must be respected unless it endangers the rights of others, public health or other factors requiring special protection. The Court, as it did not specify what these other factors requiring special protection were, left the door open to sentencing in future cases for or against objection, depending on the circumstances.

If the person requiring the treatment is a minor, it should be understood that the right to life and to health of the minor may not be put in jeopardy by the 
freedom of conscience of the parents. Thus, if the refusal of the adult to accept the treatment leads to the death of the minor, it becomes a case of criminal responsibility. The protection of the parents' position was not affected because their child, invoking his religion, refused to have a blood transfusion, although his life was in danger, and this is supported by many examples in positive law. In these cases it cannot be said that there is no instance of misconduct; although the parents obviously did not wish the child to die, they were aware that this would happen if the transfusion was not given. The Court applies the extenuating circumstance of obfuscation and, regarding this case, declared itself «in favour of a partial pardon if this were requested by the defendants». This last sentence by the Supreme Court leads us to believe that the Court has limited itself to the strict application of the law so as not to open up a whole kaleidoscope of possibilities in order to prevent the proliferation of cases of this sort, whilst at the same time understanding the particular situation which has been created.

The case analysed is perhaps the most striking example of the conflict between public duty, represented by the law, and moral obligations.

The second limit, as we have already mentioned, is public order ${ }^{34}$, and once again I deem it necessary to refer to the sentence issued by the Constitutional Court on 15th February, 2001, according to which «the public order clause coherent with the general principle of freedom which includes the constitutional recognition of fundamental rights obliges us to consider that, as a general rule, only when the courts have proven the existence of a certain danger for "public safety, health and morality", as understood by a democratic society, will it be relevant to cite public order as a limit to the exercise of the right to freedom of religion and worship (...) Only by means of a final judgement and with reference to the practices or activities of the group, may the existence of conduct contrary to public order be deemed to exists In the sentence one can see how the Court resorts to applying legal concepts such as public order, which has an undetermined nature, although in a way which will not hinder the exercise of the fundamental right to freedom of religion.

\section{CONCLUSIONS}

The profound changes that the coming of democracy and the enactment of the Constitution have brought about in Spanish law have been particularly

${ }^{34}$ Collate: PARDO PRIETO, P., RODRÍGUEZ GARCÍA, J. A.: «La moral pública como límite de la libertad ideológica y religiosa. Estudio jurisprudencial» in La libertad religiosa y de conciencia ante la justicia constitucional/ coord. por Javier Martínez-Torrón, Granada, 1998, pp. 743-759. 
radical in Law and Religion issues ${ }^{35}$. This transformation ${ }^{36}$ has taken place to a great extent due to the work of the judiciary, and can be followed by studying how case-law has developed in two fields: criminal law and Church and State relations based on the principle of cooperation.

I am of the opinion that Criminal Law is unique in reflecting where the authorities of a given State stand in relation to religious issues. To put it another way: how criminal law protects religion depends on the attitude the State adopts towards religious matters. In a denominational system of government, the State is a subject of the faith, which results in a special legal protection for the religion it professes. There are different degrees in this policy of legal involvement in religious matters. At its most extreme, a denominational system may forbid the practice of any religion other than the official one, prosecuting crimes such as proselytism. Milder forms of denominationalism will establish a system of legal protection of a specific form of religion without excluding other forms, but in case of conflict the rules will favor the prevailing denomination. Bearing in mind that during the first period under consideration Spain is still a denominational State, I chose to focus on criminal matters and selected several sentences in this field.

Under Franco's regime, the Penal Code (1944), in keeping with the times, restored the principle of protection through criminal law in exclusive favor of Catholicism, a principle that had been abandoned by the Republican Constitution. The Penal Code included a part entitled «Crimes against the Catholic Religion». However, although most of the Penal Code remained in force all along the period, the Second Vatican Council forced the Spanish authorities to soften this form of exclusive legal protection of Catholicism through criminal law. Catholicism, nevertheless, maintained a privileged status. The legal reform in this field took place in 1971, only four years before the end of this first period. After the reform, the Part of the Penal Code devoted to the Crimes against the Catholic Religion changed title, which then read «Crimes against Religious Freedom, the State Religion and other Denominations».

As I have pointed out, the crime of blasphemy is doubtless the offense that best reveals the position taken by the State. It is a crime with clear denominational coloring. It may come as a surprise that, even though Spain is

${ }^{35}$ Collate: SOUTO PAZ, J. A. «La transición política en España y la cuestión religiosa», in OLIR, p. 10.

36 Collate: MARTÍNEZ TORRÓN, J. «La Ley Orgánica de Libertad Religiosa, veintiocho años después», in: Revista General de Derecho Canónico y Derecho Eclesiástico del Estado, , n. ${ }^{1}$, 2009. 
now a non-denominational State, its criminal law includes a crime that is reminiscent of the crime of blasphemy. The evolution of case-law concerning blasphemy appears clearly in the work I have submitted. In the first judgment, issued on 18 March 1975, the court analyses whether the crime of blasphemy exists, pondering the elements of the crime, which were offense to God and grave scandal. In the sentence issued on 14 May 1977, a new factor was introduced: the infringement of the rules of civil coexistence. Thus the court moved away from strictly religious factors and considered a new issue, such as civil coexistence. What had been attacked was not the prevailing religion, but public order. It could be said that this sentence was already close to defining the limits later set to the exercise of freedom of speech by the 1978 Constitution.

As far as religion-State relations are concerned, the principle of cooperation enshrined in the 1978 Spanish Constitution is the result of a historical process, in which two factors have come into play: on the one hand, the Spanish tradition of State religion, which has left its mark on religion-State relations, regulated through various concordats; on the other hand, the spirit of promotion that befits the social and democratic State. Such a spirit, or principle, of promotion entails that the State shall not confine itself to securing the exercise of fundamental rights by the citizens, but that it is under the obligation to promote or stimulate the exercise of such rights through the adequate legislation.

As a result, Article 16.3 of the Constitution proclaims that «the public authorities shall take the religious beliefs of Spanish society into account and shall in consequence establish appropriate relations of cooperation with the Catholic Church and the rest of denominations».

This solution is logical: The Church and the State have established relations through concordats. Now that freedom and equality are to be promoted, relations of the same type must be entertained with other denominations and religious entities.

As I have noted before, State neutrality towards every denomination is not the result of State indifference towards religion. The Spanish Constitution mandates the State to entertain relations with the Catholic Church and the other religious entities. This principle inspires a system that moves away from anti-clericalism, a force strong at times in Spanish history, and implies a State that must not disregard the religious factor. It is no business of the State whether there are one or two thousand churches in Spain as a result of the exercise of religious freedom. However, it must create the conditions under which churches, if such is their will, can be established and flourish under the law. The State must seek pluralism, but it must be neutral at the same time. 
In order to achieve these goals, law-makers have established a system whereby religious groups have the opportunity to put into practice the principle of cooperation ${ }^{37}$. This principle is the apex and the real novelty of the constitutional system. If there is an unprecedented feature in Spanish law after 1978, this is precisely the duty of recognition and cooperation imposed on public authorities. In view of this, a selection has been made of sentences dealing with the legal requirements for registration in the Registry of Religious Entities. Registration has been made a prior step and an indispensable requirement for reaching agreements with the State.

A standard seems to be clear: an entity must have religious goals to qualify for registration in the Registry of Religious Entities. The courts held that the requirements established by the Freedom of Religion Act are merely intended to identify religious entities. With one exception: religious goals, whose presence must be verified, and whose absence entails denial of registration.

Regarding the third period under analysis, I have continued to use the same criterion as in the second period. The Spanish system offers a legal principle on which recognition of religious freedom and its practice can be grounded: the principle of cooperation. This time, however, I have chosen to study a sentence issued by the Constitutional Court. My choice derives from two reasons. The first one is that, with this judgment of 2001, the Constitutional Court has modified all the previous case-law on the issue. The second reason is that the Constitutional Court is the supreme interpreter of the Constitution, which is the source of our present legal system, a fact that allows me to properly crown my study of case-law.

The Constitutional Court rebuked the legal position consistently held until then by the Supreme Court all along the democratic period. Now, it turned out, religious goals are not to be analyzed at all. Registry officials must consider them in the same light as the legal residence, that is, without any judgment, assessment or evaluation. For registration to be granted, it suffices that the existence of religious goals be stated in the application for registration. This sentence goes far beyond, for it affirms that one cannot determine what is, or is not, religious. Therefore, it is safe to say that this judgment has made the present system stagger. In a context where we have religious freedom, a Freedom of Religion Act, and a Registry of Religious Entities, our highest court has

${ }^{37}$ Collate: PARDO PRIETO, P., «Laicidad y Acuerdos vigentes con la Iglesia católica», en Laicidad y Libertades, n. ${ }^{\circ}$ 5, 2005, p. 338, CONTRERAS MAZARÍO, J. M., CELADOR ANTÓN, O., "Estatuto de laicidad y Acuerdos con la Santa Sede: dos cuestiones a debate». Working paper/2005, in Fundación Alternativas, p. 18. 
come to the conclusion that the religious factor cannot be determined. This is probably the reason why Spanish law-makers are considering a review of the legislation on these matters.

In the analysis of the early Supreme Court judgements, one can observe a defence of the Catholic faith established by the secular State through legislation, even from a criminal perspective, although one can also see how the Court prepares itself for the changes which are to come, bending the law with pious, kind intentions. With the arrival of the Constitution, the aim is to protect religious sentiment, regardless of what it may be, and the protection of the predominant religion evolves into protection of constitutional principles. While it is true that there is no radical change and that, as we have seen, the Catholic Church enjoys a privileged position, it is none the less true that criteria such as collective morals vary from one period to another. Moreover, the evolution from a non-secular to a secular State brings about changes in case-law regarding offences related to the protection of morals. Initially, attacks on religious principles are punished by criminal law. Later, this solution will be replaced by the criminal protection of ethical beliefs which now bear a necessary relation to religion. Fear of new religious movements abates in Spanish courts and the interpretation of criteria such as religious aims broadens, to such an extent that, today, it is my belief that the Freedom of Religion Act has become outdated and is insufficient in the light of constitutional case-law ${ }^{38}$.

To sum up, high court judgments on religious matters have, in my opinion, been more advanced than legislative changes. I consider that case-law has been one step ahead of legislation in this area. This could come as a surprise, given the received wisdom that legislators tend to be more radical than judges. Ever since the French revolution, the traditional image of a radical law-changing body is a political assembly, not a court. Law-makers can change a legal system through a single act of legislation, whereas the change brought about by courts, which operate on a case-by-case basis, is obviously more limited in its direct effects and more constrained by the factual circumstances of the cases brought before them. Legislators focus on the implementation of policies through legislation. Judges concern themselves with the organic development of the body of law they interpret and apply. In their attitude towards the law, courts tend to be conservative, whereas law-makers tend to be more progressive and less preoccupied with practice and precedent. It could have been all the more so during the Spanish transition towards a secular State, when a considerable part of legislators were new to politics and law-making. Yet the courts, the high

\footnotetext{
38 STC 141/2000, STC 46/2001.
} 
courts in particular, were effective agents of change and a source of legal dynamism and progressive case-law during the consolidation of the Spanish constitutional democracy. The trend continues: the latest regulation on teachers of religion and labour relations ${ }^{39}$ is admittedly based on a previous sentence by the Constitutional Court ${ }^{40}$ determining the legal status of teachers of religion in public schools. Moving beyond the clichés about the continental systems of law, Spanish case-law functions regularly as the source and inspiration of legislation.

Spain has faced three critical junctures in religion-State relations since 1975. These three moments, with their corresponding periods of direct influence, are 1978, 1980 and 1992. Their effect has been the transformation from dictatorship to a democratic and secular State, the consolidation of a human rights-based legal order, and the emergence of a multi-religious system whereby religious entities entertain direct relations with the State, and citizens are seen both as free individuals practicing the religion of their choice and as members of a religious group. These effects are, broadly speaking, the result of a protracted struggle between conservative and progressive forces, both social and political. Some of the problems posed by such a struggle have found solutions in the decisions adopted by the Spanish high judiciary, a fact that underlines the role of this secular elite in critical junctures, a topic so far under-researched. In the analysis of historical critical junctures, the emphasis has been rightly placed on regime change or policy formation. Yet the function of the courts is also decisive to consolidate the changes in the long run, and to insert the assumptions of the new system in the very fabric of law and society.

It could be said that judges are critical agents at critical junctures, especially when the systematic change brought about by the latter puts a high premium on constitutional issues and legislative measures. Judges are special because they are entrusted with the interpretation and application of the law, but they perform this function within a legal system whose foundations they do not create, yet they help to establish and develop. Judges, moreover, are not policy-makers, which means that, in principle, they are unconcerned with the social impact of governmental measures or parliamentary acts. In the Spanish system, their focus is on the law and how it applies to the case brought before them. These traits pertaining to the judicial function may account for the great importance that high courts have had in the Spanish transition towards a constitutional democracy respectful of human rights. They also explain why their role could prove decisive to face the challenges issued by an assertive secularism now

39 RD 696/2007, 1st June.

40 STC 38/2007, 15 February. 
emerging in Spain. It has been claimed that «assertive secularism seems to be incompatible with any religion that has public claims" ${ }^{\prime 1}$. However, the judiciary is precisely the body that, on a case-by-case basis, can fashion solutions that gradually accommodate the claims of both secularists and religious entities in the public realm.

\begin{abstract}
Since 1975, Spain has undergone a period of unprecedented political changes. Inspired by a democratic model in which individual rights and freedoms are effectively protected, a legal transformation has taken place in every field of Spanish Law since Democracy. It is fascinating to verify how radical the changes in religious matters have been: Spain has evolved from a Catholic non-secular State to a secular, non-denominational State in which religious freedom is a basic principle. The analysis of case-law is an essential part of the study of this period, for it allows us to see how legislation changes and judicial breakthroughs do not always go together. Thus during the first years of democratic transition the yearning for change was so great that the Supreme Court, drawing up highly permissive legal doctrines, took the lead in the recognition of rights, only to later adapt its decisions to fit in with the new legislation. Having focused on the Spanish experience, this paper will end with comparative considerations on the role of the judiciary in periods of radical political transformations and the complex relation between legislatures and high judicial bodies. It will also highlight the part played by the secular elite of high court judges in advancing and consolidating the systematic change made possible by the critical junctures identified in the recent history of Spanish religion-State relations.
\end{abstract}

${ }^{41}$ AHMET, K: «Passive and Assertive Secularism. Historical Conditions, Ideological Struggles, and State Policies toward Religion», World Politics, 59, July, 2007, 594. 